Article

\title{
The Potential of Impact and Integral Investing for Sustainable Social Development and the Role of Academia in Their Dissemination
}

\author{
Jaroslava Kubátová *(D) and Ondřej Kročil \\ Department of Applied Economics, Faculty of Arts, Palacký University Olomouc, Kř́žzovského 12, \\ 77180 Olomouc, Czech Republic; ondrej.krocil@upol.cz \\ * Correspondence: jaroslava.kubatova@upol.cz
}

Received: 3 August 2020; Accepted: 25 August 2020; Published: 26 August 2020

\begin{abstract}
With the increasing challenges our society faces, ranging from environmental issues to the current coronavirus crisis, interest in a new way of investing, known as impact investing, has also been increasing. In addition, recently, an even more conscious way of investing, known as integral investing, has appeared. In this article, the concepts of impact investing and integral investing are described and compared and their positive impacts on society are documented. The importance of people and leaders with corresponding ethics, morals, and personal values for the success of the investments is explained. As both impact and integral investing have the potential to meet the challenges of present-day society and to contribute to its further sustainable development, they should be addressed in academic research and higher education. Therefore, this article seeks to answer the question of whether these concepts are reflected in academia. To answer this question, a bibliometric analysis was conducted. The findings show that there is a modest but growing academic interest in impact investing and very little interest in integral investing. Reasons to take these topics into account in research and education are discussed in the final part of the article.
\end{abstract}

Keywords: impact investing; integral investing; sustainable social development; academia

\section{Introduction}

One of the predominant beliefs in the fields of economics, business, and finance is that only measurable indicators are assessable. The main measurable criterion has become profit. The result is that too often an increase in profits is achieved at the expense of people and the planet. However, as ongoing societal and environmental issues have repeatedly demonstrated, the profit-only measurement principle is a terrible misconception because it is not sustainable in the long-term [1,2].

Since its invention, money has become one of the most treasured, if not the most important, driving forces in human life, the world economy, and politics. Bozesan [3] argues that in general, we have forgotten that money is a human creation made to serve us and we are instead serving it because we see it as a source of absolute power and authority. This has come about partly due to aspirations to shape business economics into a science that does not accept immeasurable human values, ethics, and morals [4] (p. 4).

However, in light of today's increasing global challenges, individual frustrations with the profit-only oriented business world has also increased [5]. Senge, Scharmer, Jaworski, and Flowers [6] point out that addressing the current challenges in an integral fashion requires massive capital but also higher levels of consciousness.

Bozesan $[1,3,7]$ has shown that investors not solely focused on profit do exist within society. They use their wealth to address current challenges by experimenting with investment models that 
both transcend and yet still include the profit-only oriented models. These people have realized that we are all part of a greater whole and they feel the need to leverage their money and talents to make a meaningful and impactful contribution to the sustainability of the planet. As the idea of our mutual interconnection might have sounded overly spiritual in some countries or cultures, just a short time ago, the outbreak of the novel coronavirus around the world at the beginning of 2020 has made it apparent that it is actually true. As Sedláček [8] puts it, the whole planet is ill and it affects all of us. It might be a signal that we have to stop competing and instead start cooperating. We can now clearly see that we really are interconnected.

\section{The Concepts of Impact Investing and Integral Investing}

Conventionally, investing, hereinafter referred to as traditional investing, refers to the use of money to purchase shares in a company, a financial product, or other item of value such as real estate, commodities, or art. The intention is to make a profit and to maximize the return of investment [9]. Only financial criteria (profit metrics) are used to assess the success of traditional investments.

A progressive alternative to traditional investing appeared according to a study coauthored by companies Robeco, Booz and Co. [10] in 1985. Bozesan [1] argues that this year can be seen as the birth year of impact investing. However, Höchstädter and Scheck [11] argue that the term impact investing was coined in 2007, when the Rockefeller Foundation invited leaders in finance, philanthropy, and development to discuss the need for and means of building a global industry that strives for investments with a positive social and environmental impact [12]. In 2009, the Global Impact Investing Network (GIIN), a nonprofit member organization, was established. GIIN defines impact investments as "investments made with the intention to generate positive, measurable social and environmental impact alongside a financial return" [13]. Impact investing became better known in 2011 through a book by the same title written by Bugg-Levine and Emerson [14].

With a growing recognition of the power of investment capital to address social and environmental challenges, impact investing has attracted the attention of an increasing number of investors of all types and from all over the world. Over 50\% of active impact investing organizations made their first investment in the past decade. In 2019, there were over 1340 organizations managing USD 502 billion in impact investing assets worldwide [15]. The success of impact investing is measured through financial criteria alongside Environmental, Social, and Governance (ESG) criteria [16]. Based on Freireich and Fulton [17] and Robeco, Booz and Co [10] Bozesan [18] summarizes the key ESG criteria as follows:

Environmental Criteria:

- Climate change, water scarcity

- Local environmental pollution and waste management

- New regulations beyond environmental product liability

- New markets for environmentally friendly products and services

Social Criteria:

- Workplace health and safety

- Knowledge and human capital management

- Labor and human rights issues within companies and their supply chains

- Government and community relations

\section{Governance Criteria:}

- Board structure and accountability

- Accounting and disclosure practices, transparency

- Executive compensation

- Management of corruption and bribery issues 
Nevertheless, Bozesan [7] stresses the need for an even more developed investing model in which financial returns must be inseparable from a deep impact on the social, environmental, cultural, and behavioral aspects of reality, as well as from sustainable human development and evolution. She introduces the concept of integral investing. This model, based on Habermas's philosophy [19] and integral theory [20], goes beyond traditional financial and legal due diligence, includes ESG measurements, and adds cultural, behavioral, and consciousness metrics. In addition to the concept of integral investing, Bozesan [18] both developed and tested in practice the Theta model as a de-risking decision-making tool for investors. The application of the Theta model integrates financial criteria with environmental, social, and governance criteria, as well as with behavioral, cultural, and even individual assessment metrics. Bozesan [16] claims that more than 80 percent of the risk can be addressed by performing integral due diligence on the team. It is therefore extremely important to assess team alignment and common values within the team, as well as the ethics, morals, and personal values of team members. "Team" here refers to the whole range of stakeholders, i.e., the applicants, investors, suppliers, and other contributors.

The concepts of traditional investing, impact investing, and integral investing are compared in Table 1. The metrics used for this comparison are investment aims and successes. The aims express the intentions of the investors. These metrics represent the indicators used by investors in the decision-making process about the investment, and in the case of a positive decision they also serve as investment performance indicators.

Table 1. Comparison of traditional, impact and integral investing.

\begin{tabular}{|c|c|c|c|}
\hline Characteristic & Traditional Investing & Impact Investing & Integral Investing \\
\hline Aims & Profit & $\begin{array}{c}\text { Profit } \\
+ \text { Positive societal or/and } \\
\text { environmental impact }\end{array}$ & $\begin{array}{c}\text { Profit } \\
\text { Positive societal and/or environmental impact } \\
+ \text { Positive cultural and behavioral aspects } \\
\text { + Human development and evolution }\end{array}$ \\
\hline Metrics & Profit metrics & $\begin{array}{l}\text { Profit metrics } \\
+ \text { ESG criteria }\end{array}$ & $\begin{array}{c}\text { Profit metrics } \\
\text { ESG criteria } \\
+ \text { Team culture } \\
+ \text { Ethics, morals, and personal values of } \\
\text { team members }\end{array}$ \\
\hline
\end{tabular}

Source: Own elaboration based on $[1-3,7,16,18]$.

The aim of traditional investing is simply to make a profit. The general metric is profitability. The aim of impact investing is to make a profit and to have a positive societal and/or environmental impact. The metrics are profitability and the ability to meet the ESG criteria. The aim of integral investing is to make a profit and to have a positive societal and/or environmental impact, and to support positive cultural and behavioral aspects of reality as well as human development and evolution. The metrics are profitability, the ability to meet ESG criteria, and moreover, team culture including the ethics, morals, and personal values of team members. Bozesan $[16,18]$ addresses the problem of the measurability of the metrics in deep detail within the Theta model.

At present there is quite a broad consensus that profit-only oriented activities harm society and the whole ecosystem [4,21-24]. Impact investing supports businesses that have a positive impact on society and the environment. They must be transparent and avoid corruption, bribery, and unacceptably high executive compensations. Integral investing goes even further in its requirements on businesses. When assessing an investment project, the ethics, morals, and personal values of the people involved are strongly taken into consideration. The reason is that in order to solve pressing global problems, our global society needs to move from competition to cooperation. The foundation for cooperation is mutual trust. In addition, trust can be built only on the basis of high ethics, morals, and values that take into consideration the needs and interests of the whole global society. However, profit is still important, rather, its role and importance have to be viewed from a new perspective. Profit has to ensure the sustainability of a business, as well as of the global ecosystem, which means that it must not 
cause negative externalities. Here, academia plays a crucial role. Academic research has the potential to shed more light on the topic of impact and integral investing. The available knowledge can be distributed at universities to encourage more impact and integral investments. To find out whether academia reflects the topics of impact and integral investing, a bibliometric analysis was conducted and its results are presented further in the article.

\section{Research Method-Bibliometric Analysis}

Bibliometric methods are used for research evaluation in multiple fields [25]. Bibliometric analysis, originally described by Pritchard [26], consists of applying statistical methods to determine changes and to detect tendencies in a given scientific research topic [27]. The validity of bibliometric analysis for research evaluation lies largely in the representativeness of the used scientific publications databases. Today, Web of Science (WoS) and Scopus are the main sources for studying and comparing different scientific fields. The Web of Science Core Collection, which is used for this research, contains over 159 million publication records [28]. Scopus, also used for this research, contains over 77 million publication records [29]. Nevertheless, WoS and Scopus should be used cautiously, particularly when comparing different fields, countries, and languages [25]. When conducting a bibliometric analysis, one issue that needs to be addressed is that many publications are recorded in both WoS and Scopus. Some research papers therefore analyze only the WoS records $[27,30]$.

In order to achieve the most complete results as possible, in this research all unique records, i.e., the union of records (Figure 1), from either WoS (core collection) or Scopus are analyzed. If the number of records in WoS is $\mathrm{W}$ and the number of records in Scopus is $\mathrm{S}$, the total number of unique records is $|W \cup S|=|W|+|S|-|W \cap S|$.

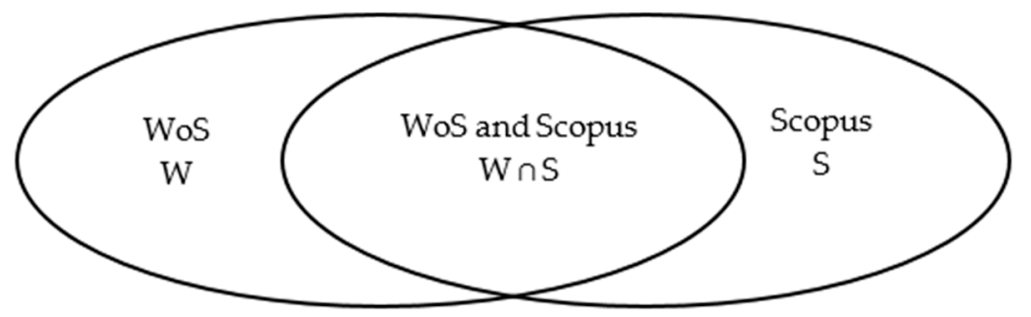

Figure 1. Records in Web of Science (WoS) and/or in Scopus. Source: Own elaboration.

The key terms for this bibliometric analysis were "impact investing" or "impact investment" and "integral investing" or "integral investment". This is because investing is a concept, whereas investment is an activity and both theory and practice is important from the point of the view of this research. The terms were searched in the title, abstract, or key words of the recorded publications; the "or" operator means that either or both terms occur. The searches in WoS and Scopus were conducted on 29 April, 2020. No other search conditions or limits were set.

The research questions to be answered for investing concepts or activities were as follows:

1. What is the frequency of publications in years?

2. In which research fields was the published research conducted?

3. What are the types of documents in which the research was published? Are there any journals dedicated to this subject?

4. How broadly are the publications cited?

5. What are the languages of the publications and in which countries was the research published?

6. Who are the funders of the research? 


\section{Impact Investing or Impact Investment-Bibliometric Analysis Results}

For the key term "impact investing" or "impact investment", 292 records were found in Scopus and 213 in WoS. After deducting duplicities, it represented 348 unique records in WoS or Scopus. To answer the research questions, these records were analyzed further.

\subsection{Frequency of Publications in Years}

The oldest record found was from 1989 and no more than 3 publications per year were recorded until 2010; altogether, 13 publications were recorded in this period. The frequency of recorded publications has increased since 2011, the numbers are shown in Table 2.

Table 2. Numbers of publications on the topic of impact investing or impact investment in WoS or Scopus since 2011.

\begin{tabular}{ccccccccccc}
\hline Year & $\mathbf{2 0 1 1}$ & $\mathbf{2 0 1 2}$ & $\mathbf{2 0 1 3}$ & $\mathbf{2 0 1 4}$ & $\mathbf{2 0 1 5}$ & $\mathbf{2 0 1 6}$ & $\mathbf{2 0 1 7}$ & $\mathbf{2 0 1 8}$ & $\mathbf{2 0 1 9}$ & $\mathbf{2 0 2 0}$ \\
\hline Scopus & 10 & 11 & 12 & 17 & 23 & 44 & 38 & 53 & 52 & 21 \\
WoS & 0 & 1 & 2 & 2 & 10 & 9 & 11 & 7 & 9 & 3 \\
Total & 10 & 12 & 14 & 19 & 33 & 51 & 49 & 60 & 61 & 24 \\
\hline
\end{tabular}

${ }^{1}$ January-April. Source: Own elaboration.

The increase in topical publications since 2011 is consistent with the statement above about the growing popularity of impact investing after the book Impact Investing: Transforming How We Make Money While Making a Difference was published [14]. However, this book is recorded neither in WoS nor in Scopus. Within the methodology used in this research, it is not possible to prove that this book started the interest in impact investing.

Despite the growing numbers of publications on the topic of impact investing or impact investment, their share of the total number of publications on investing or investment is still minor. There are about 320 thousand publications on investment and investing recorded in Scopus and about 215,000 in WoS. While there will certainly be many duplicate records, the fraction of publications on impact investing or impact investment represents no more than about one one-thousandth. It means that the topic of impact investment or impact investing is still a rare research subject.

\subsection{Research Fields}

Three research fields that the publications are associated with are strongly dominant:

(1) Business, Management, and Accounting with 192 publications in total, (2) Social Science with 138 publications, and (3) Economics, econometrics, and Finance with 132 publications. Fourth was Environmental Science with 42 publications. It must be taken into account that one publication can be associated with several research fields and also that the declared research fields are not exactly the same in WoS and in Scopus. Nevertheless, the dominance of the three research fields mentioned above is still apparent. It also means that the terms impact investing or impact investment are generally linked to these fields and are not used as established concepts in other fields.

\subsection{Document Types and Subject-Related Journals}

The majority of publications were journal articles. The number of articles, as well as of other documents, are shown in Table 3. In Scopus, each publication has one classification, whereas in WoS a publication can be classified as several document types. Even with this limitation the predominance of journal articles is apparent.

The highest number of articles, twelve, was published in the Journal of Sustainable Finance \& Investment. However, all of them were published in Volume 3, 2013-Issue 2: Impact investing. Other journals with at least five topical articles were Sustainability (eight articles), Journal of Social 
Entrepreneurship (six articles) and Social Responsibility Journal (five articles). It cannot be concluded that there is a journal specializing in impact investing or impact investment.

Table 3. Numbers of publications on the topic of impact investing or impact investment in WoS or Scopus according to document types.

\begin{tabular}{ccc}
\hline Document Type & Scopus & WoS \\
\hline Article & 203 & 35 \\
Book Chapter & 34 & 14 \\
Conference Paper & 22 & 13 \\
Review & 19 & 1 \\
Book & 5 & 1 \\
Editorial & 4 & 6 \\
Note & 4 & - \\
Short Survey & 1 & - \\
\hline \multicolumn{2}{c}{ Source: Own elaboration. }
\end{tabular}

\subsection{Citations}

About $60 \%$ of publications (209 out of 348) were cited at least once. The total number of citations was 2255. In general, the number of citations correlates positively with the time the research was published, although the total number of citations for the recent publications is quite high (see Table 4), even publications from this year, i.e., 2020, have already been cited.

Table 4. Numbers of citations in recent years.

\begin{tabular}{ccccc}
\hline Year & $\mathbf{2 0 1 7}$ & $\mathbf{2 0 1 8}$ & $\mathbf{2 0 1 9}$ & $\mathbf{2 0 2 0}^{\mathbf{1}}$ \\
\hline Number of publications & 49 & 60 & 61 & 24 \\
Number of citations & 186 & 122 & 85 & 13 \\
\hline
\end{tabular}

${ }^{1}$ January-April. Source: Own elaboration.

It was shown that the relative numbers of publications on impact investing or impact investment are low, nevertheless, they are cited relatively frequently, meaning that the topic of impact investing is currently of research interest.

\subsection{Countries and Languages}

While publications on the topic of impact investing or impact investment were published in more than 50 countries, most publications originate in the United States. The countries where at least 20 titles were published are shown in Table 5.

Table 5. Countries with at least 20 publications on the topic of impact investing or investment.

\begin{tabular}{cc}
\hline Country & Number of Publications \\
\hline United States & 89 \\
United & 44 \\
Kingdom & 31 \\
Italy & 27 \\
Australia & 20 \\
Canada &
\end{tabular}

The most widely used language in the publications is English (in 332 out of 348 publications, i.e., 95\%). The other languages were French, German, Italian, Russian, Spanish, and Ukrainian. English is a common language in academia so it is natural that it predominates in publications. On the other hand, the results show that impact investing or impact investment is a global topic. 


\subsection{Funding}

More than 60 institutions are referred to as funding sponsors in the publications, but only ten of them more than once. Their names, numbers of supported publications, and the years of publications are shown in Table 6.

Table 6. Funding sponsors of more than one publication on the topic of integral investing or investment.

\begin{tabular}{cc}
\hline Funding Sponsor & Number of Funded Publications (Years) \\
\hline Rockefeller Foundation & $7(2012,2013,2016,2018(3 \times), 2019)$ \\
National Science Foundation & $4(2014,2016,2018(2 \times))$ \\
Bill and Melinda Gates Foundation & $3(2014,2016,2018)$ \\
European Commission & $2(2017,2019)$ \\
Ford Foundation & $2(2014,2019)$ \\
Medical Research Council & $2(2014,2016)$ \\
Silicon Valley Community Foundation & $2(2014,2016)$ \\
Social Sciences and Humanities Research Council of Canada & $2(2013,2018)$ \\
World Bank Group & $2(2019(2 \times))$ \\
World Health Organization & $2(2017,2018)$ \\
\hline
\end{tabular}

Source: Own elaboration.

Support by the listed institutions was most often provided in recent years. The Rockefeller Foundation has been supporting research in the area of impact investing or investment continuously since 2012. This finding corresponds with the Rockefeller Foundation's activities mentioned above.

\section{Integral Investing or Integral Investment—Bibliometric Analysis Results}

For the key terms "integral investing" or "integral investment", eight records were found in Scopus and two in WoS. There were no duplicate records so ten unique records were found for these key terms. It means that this topic has been of very little research interest. Nevertheless, these few records are analyzed further and within this range the research questions are answered.

\subsection{Frequency of Publications in Years}

The oldest record was found in Scopus and it was a publication from 1985. One record from 2009 and one from 2010 were also found in Scopus. However, Bozesan [7] introduced the term in 2013. The number of publications since 2013 are shown in Table 7. The total number of these publications is seven. The numbers of publications are very low and is the only trend that can be noted.

Table 7. Numbers of publications on the topic of integral investing or integral investment in WoS or Scopus since 2013.

\begin{tabular}{ccccccccc}
\hline Year & 2013 & $\mathbf{2 0 1 4}$ & $\mathbf{2 0 1 5}$ & $\mathbf{2 0 1 6}$ & $\mathbf{2 0 1 7}$ & $\mathbf{2 0 1 8}$ & $\mathbf{2 0 1 9}$ & $\mathbf{2 0 2 0}^{\mathbf{1}}$ \\
\hline Scopus & 3 & 1 & - & 1 & - & - & - & - \\
WoS & - & - & - & & - & 1 & 1 & - \\
Total & 3 & 1 & - & 1 & - & 1 & 1 & - \\
\hline
\end{tabular}

\subsection{Research Fields}

The research fields associated with the publications are shown in Table 8 (one publication can be associated with several research fields).

With only ten recorded publications on the topic of integral investing, it is not possible to classify any associated research fields as apparently dominant. Half of the publications are associated with Social Science and four with Material Science. Only one publication is associated with Economics, Econometrics, and Finance, and none with Business, Management, and Accounting. Apparently, the terms 
integral investing or integral investment are connected not only to business and finance, but also to other fields, and were already in use before Bozesan [7] came up with the term in the field of finance.

Table 8. Numbers of publications on the topic of integral investing or integral investment associated with particular research fields.

\begin{tabular}{cc}
\hline Research Field & Number of Publications \\
\hline Social Science & 5 \\
Material Science & 4 \\
Arts and Humanities & 3 \\
Physics and Astronomy & 2 \\
Engineering & 2 \\
Economics, Econometrics and Finance & 1 \\
\hline
\end{tabular}

Source: Own elaboration.

\subsection{Document Types and Subject-Related Journals}

Out of the 10 found publications, 9 are journal articles and one is a book chapter (see Table 9).

Table 9. Numbers of publications on the topic of integral investing or integral investment in WoS or Scopus according to document types.

\begin{tabular}{ccc}
\hline Document Type & Scopus & WoS \\
\hline Article & 7 & 2 \\
Book Chapter & 1 & 0 \\
\hline \multicolumn{2}{c}{ Source: Own elaboration. }
\end{tabular}

Due to the low total number of publications, no particular journal can be classified as their dominant source. Two articles were published in the Journal of Integral Theory and Practice, Volume 8, Issue 1-2 in 2013 [1,7] and two in the journal of Zhuzao/Foundry in 2009 and 2010. The Journal of Integral Theory and Practice is associated with Social Science and with Art and Humanities, and the journal of Zhuzao/Foundry is associated with Material Science. This finding supports the concerns about the suitability of the term of integral investing for investing focused on the aims referred to in Table 1.

\subsection{Citations}

Out of the seven titles published since 2013 (i.e., after Bozesan [7] introduced the term integral investing) only the publications recorded in Scopus have been cited (see Table 10), with the total number of citations at 11 .

Table 10. Numbers of citations.

\begin{tabular}{|c|c|c|c|c|c|c|c|c|}
\hline Year & 2013 & 2014 & 2015 & 2016 & 2017 & 2018 & 2019 & $2020^{1}$ \\
\hline Publications & 3 & 1 & & 1 & & 1 & 1 & \\
\hline Number of citations & 4 & 4 & & 3 & & 0 & 0 & \\
\hline
\end{tabular}

The citations of the publications from 2013 and 2016 are related to the fields of Social Science and Arts and Humanities, whereas the citations of the publication from 2014 to Material Science. The most recent publications from 2018 and 2019 have not been cited yet, although one is related to the field of Hospitality, Leisure, Sport, and Tourism, and the other to Remote Sensing. The three oldest publications from 1985, 2009 and 2010, all of them from the field of Material Science, have been cited 22 times. The problem with the term integral investing also applies here. 


\subsection{Countries and Languages}

The spectrum of countries where the titles were published, as well as the spectrum of languages that the titles are written in, are relatively broad. The titles published in 2013 and later originate in Brazil, China, Germany, Ukraine, and the U.S., four are in English and the others are in Chinese, Portuguese, and Ukrainian. Due to the low number of publications and the problem with the term integral investing, no conclusion can be made regarding their international impact.

\subsection{Funding}

The answer to the last research question in this case is brief: No funding sponsor is declared in any of the publications on the topic of integral investing or integral investment.

\section{Bibliometric Analyses-Summary and Major Trends in the Literature}

Bibliometric analyses of the publications on the topics of impact investing or impact investment and integral investing or integral investment recorded in WoS or in Scopus were conducted in this research paper to answer the research questions mentioned above.

To summarize the findings, it is possible to say that publications on these topics represent a very small fraction, barely one-thousandth, of the publications on investing or investment. None of the topics are therefore of a broad research interest. Nevertheless, the terms impact investing or impact investment are well established and used in the field of Finance and knowledge sharing in impact investing or impact investment in the research community is growing.

The most frequently used keywords (at least 20 times) in the publications show that the terms impact investing or impact investment are used in accordance with the GIIN definition [13]. These keywords (alongside impact investing or impact investment) are social impact, social enterprise, social finance, sustainable, responsible, and development.

Serious questions arise about the terms integral investing or integral investment. These terms were introduced and well defined in the field of Finance by Bozesan [7], but have barely received a response in academia. Moreover, even the low number of publications on this topic indicates that the term integral investment or integral investing has not been chosen well because it is also used in other technical research fields.

Even the keywords used in the publications (alongside integral investing or integral investment) indicate the problem. There are not repeatedly used keywords and only Bozesan refers to philanthropy; otherwise, keywords such as process optimization, energy consumption, numerical simulation, or stainless steel are given in the texts. Nevertheless, the problem could be solved soon as a book titled Integral Investing authored by Bozesan is supposed to be published by Springer in November 2020 [31].

The question of major trends in the literature on the subjects of impact investing and integral investing may be of interest to researchers in the field as it can help them to expand in a scientific way the boundaries of knowledge in the field. Since the number of publications on the subject of integral investing is very limited it is not possible to identify any trends so far. Moreover, the issues relating to the term impact investing itself indicate that first, basic terminology needs to be established and agreed upon. In this respect the above-mentioned book by Bozesan [31] could help considerably.

As for impact investing, thematic literature published until 2017 was reviewed by Liu [32]. According to this literature review, the academic work in impact investing is of a nascent field of research, in which there is considerable interest and potential. Nevertheless, no substantial core of ideas, theory, or data were published; the academic contributions represent diverse perspectives and approaches and share little common ground. Liu suggests building a core set of ideas, theories, and definitions to support the progressive accumulation of knowledge in the field of impact investing. The question of whether there is some change in the trends in the literature published from 2018 to April 2020 was thus examined within bibliometric analysis in this article. Expert analysis of the titles, 
keywords, and abstracts was used to answer this question and particular attention was paid to the linkage between impact investing and sustainable social development.

The trend of diverse theoretical approaches and perspectives is apparent also in the texts published after 2017. Among the analyzed publications none represents a theoretical or conceptual work focused on the theoretical framework of impact investing and alongside Liu [32], only Verrinder, Zwane, Nixon, and Vaca [33] explicitly point to this problem. Agrawal and Hockerts [34] claim that impact investments are rapidly growing; however, the research does not keep pace with the practitioners' interest. The rather practical focus of the analyzed publications supports this claim. The publications deal with impact investments in a wide range of fields, such as agriculture, housing, real estate, tourism, marine conservation, or welfare state. Social entrepreneurship is another frequently mentioned area. Terms sustainability, sustainable business, sustainable development, sustainable investing, social impact, social innovation, socially responsible investment, social tech start-ups, fairness, philanthropy, or poverty management appear in the publications frequently. References to the Sustainable Development Goals set by the United Nations [35] are often used when the meaning of impact investments is explained. Despite the persisting lack of theory in the field, it is apparent that in recent years the common understanding of the core ideas and goals of impact investing has been strongly linked to sustainable social development.

\section{Discussion and Conclusions}

In the discussion serious reasons for changes in traditional business and investing are stressed including a new strong impulse-the COVID-19 pandemic. At the same time, significant changes in thinking about the role of businesses that are already happening are documented. The importance of impact and integral investing for further development of such changes is advocated. It is concluded why and how academia can and has to play a crucial role in the dissemination of impact and integral investing to support sustainable social development.

The social benefits of profit-only oriented business are already being questioned for several decades; nevertheless, there are still very many reasons why to care about the present as well as the future of our global society. The United Nations identifies 22 Global Issues that can be solved only through global cooperation [36]. The list of the issues includes, e.g., Ageing Population, Climate Change, Health, or Poverty. A new issue well visible for everybody and affecting everybody is the COVID-19 pandemic [37]. The United Nations calls this pandemic a human, economic, and social crisis and warns that it can further worsen global issues.

On the other hand, new business concepts, such as Corporate Social Responsibility, B Corporations, Social Entrepreneurship, Economy for the Common Good, Purpose-Driven Business, Conscious Capitalism [38], or Purpose-Economy based on Steward-Ownership [39], have appeared.

In September 2019 the Business Roundtable, a non-profit association whose members are chief executive officers of major U.S. companies, issued a new Statement on the Purpose of a Corporation [40]. So far, the Statement has been signed by almost 200 chief executive officers. The signatories declare a shared fundamental commitment to all stakeholders: customers, employees, suppliers, communities, and shareholders. They commit to deliver value to all of them, for the future success of the companies, the communities, and even the country. Even though this statement focuses on the USA, it has influenced the global business environment. Moreover, there are international consulting companies among the signatories, such as Accenture, Boston Consulting Group, Deloitte, and EY, who all have the potential to share this business approach among their clients.

At the turn of 2019 and 2020, the World Economic Forum launched the Davos Manifesto 2020: The Universal Purpose of a Company in the Fourth Industrial Revolution [41]. According to this manifesto, "the purpose of a company is to engage all its stakeholders in shared and sustained value creation. In creating such value, a company serves not only its shareholders, but all its stakeholders-employees, customers, suppliers, local communities and society at large". Klaus Schwab [42], the founder and Executive Chairman of the World Economic Forum, explains, such as he calls it, that stakeholder 
capitalism offers the best opportunity to tackle today's environmental and societal challenges, whereas the profit-only focused shareholder capitalism is no longer sustainable because it neglects the fact that a company is also a social organism. Schwab points out that many people have started thinking about the role of businesses in society in this new way. One proof is the rise of impact investing as more and more investors look for ways to link environmental and societal benefits to financial returns. Moreover, as Fernandes Bella, Gonçalves Quelhas, Toledo Ferraz, and Soares Bezerra [43] argue, financial rewards are not solely sufficient to keep workers motivated because to more and more people it is important to see the meaning of their work within the surrounding community. Schwab [42] points out that companies willing to apply stakeholder capitalism will need new metrics to measure their performance and success, and he suggests the ESG criteria. However, he also emphasizes the roles of leaders. They, along with other workers in stakeholder-oriented companies, have to share and apply high personal values as well as ethical and moral qualities. To develop their business activities higher-purpose-oriented businesses need also similarly oriented investors. To assess the readiness of the leaders, workers, and even potential job seekers, the metrics suggested by Bozesan $[16,18]$ are highly suitable as part of them is targeted precisely on ethics, morals, and personal values of the people.

These shifts seemed to be a gradual evolutionary process, but with the COVID-19 global outbreak, society now needs these changes to happen very quickly to overcome the devastating impacts of the pandemic. There is no part of the global society or the world economy untouched by the pandemic and its economic impacts, whether they are rapid and direct or they take effect later [44]. The only way to meet this challenge is cooperation. The knowledge that a society cannot thrive unless all its parts thrive has been available for some time [2] but now it is apparent more than ever.

On the other hand, we can still find investment recommendations [45] such as "COVID-19 ... has crated horrific damage to the world market. ... Even though ... you can make a profit if you have a good strategy". The authors argue that "... there are several industrial sectors that gained during the pandemic and could keep this pace in the nearest future". The authors apparently assume that there is demand for investment strategies leading to fast, individual profit. They also suggest investments in companies with long term foreseen gains. The suggested companies are Microsoft, Amazon, Apple, Facebook, and Visa. Paradoxically enough, owners and CEOs of these companies are involved in socially beneficial projects or institutions. For example, the CEOs of Amazon, Apple and Visa are among the signatories of the Statement on the Purpose of a Corporation. Bill Gates, the founder of Microsoft, along with his wife Melinda Gates, run the Bill and Melinda Gates Foundation, which has also supported some research in impact investing. The founder of Facebook and his wife run the Chan Zuckerberg Initiative [46] with a motto "A Future for Everyone". It can be questioned whether these and similar foundations, e.g., Open Society Foundations, Ford Foundation, Rockefeller Foundation, or Azim Premji Foundation to name a few, make true impact or integral investments. However, the fact that they exist is another evidence that there are business people who care about the common good.

Businesses are meant to create new economic value, but this value has to be beneficial not only to themselves but to all stakeholders. Only investors of high ethical values are able to understand this and are able to recognize stakeholder-oriented business projects. Here, the role of academia is extremely important. Universities prepare future professionals, as well as political and societal leaders, are considered to be change agents in many issues including sustainability awareness. Universities have the possibility to enable academics and students to generate new ideas and new approaches evolving around serious global issues [47]. This way academia has a unique opportunity to spread the principles of sustainable investing, such as impact investing or integral investing, in their research publications, but even more importantly in the education of new investors and other decision-makers. In this context, it is necessary to draw attention to language issues. It was shown that, despite the lacking theoretical framework, the term impact investing is quite well-established whereas there are some problems with integral investing. Moreover, the terms may be translated into other languages and it could be challenging to translate them in a concise and fitting way. Thus, stressing the ideas, goals, and principles of impact and integral investing is crucial for proper understanding of these 
concepts. To proceed from traditional investing through impact investing to integral investing can be a good methodological choice.

The principles and metrics of integral investing are very suitable for the upcoming COVID-19affected era. Nevertheless, the results of the bibliometric analysis show that this investment concept is not broadly known in academia and the knowledge spreads very modestly and slowly in highly rated publications, i.e., in publications recorded in WoS or Scopus. Moreover, the term integral investing or integral investment is linked not only to the fields of Finance or Business but also for example to Material Science (per se).

On the other hand, in this research only publications recorded in WoS or Scopus were taken into account, whereas there are also sources outside these databases. When a similar search is conducted in Google Scholar the number of results is an order of magnitude higher than in WoS or in Scopus. Google Scholar does not offer tools for a relevant bibliometric analysis and does not guarantee the scientific relevance of the publications. In spite of this, to support the dissemination of the concepts of impact and integral investing, academia should also take sources of sufficient quality outside WoS and Scopus into consideration. Impact investing and integral investing are concepts with a strong potential to support sustainable recovery and development of our challenged society. They are worth being researched and included in university curricula.

Author Contributions: Conceptualization, J.K. and O.K.; Data curation, J.K.; Formal analysis, J.K. and O.K.; Methodology, J.K. and O.K.; Writing—original draft, J.K.; Writing—review \& editing, J.K. and O.K. All authors have read and agreed to the published version of the manuscript.

Funding: This research was supported by the Ministry of Education, Youth and Sports, Czech Republic, under grant IGA FF 2020001 Shifts in Entrepreneurial Approaches in the Contemporary Economy 2, received by Palacky University Olomouc.

Conflicts of Interest: The authors declare no conflict of interest.

\section{References}

1. Bozesan, M. Demystifying the future of investing: Part 1: An Investor's Perspective. J. Integral Theory Pract. 2013, 8, 19-40.

2. Brown, C. Buddhist Economics: An Enlightened Approach to the Dismal Science; Bloomsbury Press: New York, NY, USA, 2017; ISBN 978-163-286-366-9.

3. Bozesan, M. The Making of a Consciousness Leader in Business: An Integral Approach. Ph.D. Thesis, Institute of Transpersonal Psychology, Palo Alto, CA, USA, 5 March 2009.

4. Camerer, C.F.; Loewenstein, G. Behavioral economics: Past, present, future. In Advances in Behavioral Economics; Camerer, C.F., Loewenstein, G., Rabin, M., Eds.; Princeton University Press: Princeton, NJ, USA, 2004; pp. 3-51. ISBN 978-069-111-681-5.

5. Kofman, F. Conscious Business: How to Build Value Through Values; Sounds True: Boulder, CO, USA, 2006; ISBN 978-159-179-517-9.

6. Senge, P.; Scharmer, C.O.; Jaworski, J.; Flowers, B.S. Presence: An Exploration of Profound Change in People, Organizations, and Society; Currency Doubleday: New York, NY, USA, 2005; ISBN 978-038-551-680-8.

7. Bozesan, M. Demystifying the future of investing: Part 2: An Evolutionary Approach. J. Integral Theory Pract. 2013, 8, 41-56.

8. Sedláček, T. Planetární Stop Stav Celého Světa. Hospodářské Noviny. Available online: https://archiv.ihned. cz/c1-66738030-planetarni-stop-stav-celeho-sveta (accessed on 20 March 2020).

9. Mankiw, N.G. Principles of Economics, 8th ed.; Cengage Learning: Boston, MA, USA, 2018; ISBN 978-130-597-149-3.

10. Robeco, Booz \& Co. Responsible Investing: A Paradigm Shift from Niche to Mainstream. 2009. Available online: https://docplayer.net/14661389-Responsible-investing-a-paradigm-shift-from-niche-to-mainstream. html (accessed on 21 March 2020).

11. Höchstädter, A.K.; Scheck, B. What's in a name: An analysis of impact investing understandings by academics and practitioners. J. Bus. Ethics 2015, 132, 449-475. [CrossRef]

12. Harji, K.; Jackson, E.T. Accelerating Impact: Achievements, Challenges and What's Next in Building the Impact Investing Industry; The Rockefeller Foundation: New York, NY, USA, 2012. 
13. GIIN. Impact Investing. Available online: https://thegiin.org/impact-investing/ (accessed on 12 August 2020).

14. Bugg-Levine, A.; Emerson, J. Impact Investing: Transforming How We Make Money While Making a Difference; Jossey-Bass: San Francisco, CA, USA, 2011; ISBN 978-0-470-90721-4.

15. Mudaliar, A.; Dithrich, H. Sizing the Impact Investing Market. Available online: https://hegiin.org/assets/ Sizing\%20the\%20Impact\%20Investing\%20Market_webfile.pdf (accessed on 1 April 2020).

16. Bozesan, M. Integral Sustainability or How Evolutionary Forces Are Driving Investors' Trust and The Integration of People, Planet, and Profit. In Routledge Handbook of Social and Sustainable Finance; Lehner, O.M., Ed.; Routledge: New York, NY, USA, 2017; pp. 296-321. ISBN 978-113-877-754-5.

17. Freireich, J.; Fulton, K. Investing for Social and Environmental Impact: A design for Catalyzing an Emerging Industry. Available online: https://www2.deloitte.com/content/dam/Deloitte/global/Documents/ Financial-Services/gx-fsi-monitor-Investing-for-Social-and-Environmental-Impact-2009.pdf (accessed on 25 March 2020).

18. Bozesan, M. De-risking VC investing for outstanding ROI: An interdisciplinary approach toward the integration of people, planet and profit. ACRN J. Finance Risk Perspect. 2015, 4, 49-71. [CrossRef]

19. Habermas, J. Postmetaphysical Thinking: Philosophical Essays; MIT Press: Cambridge, MA, USA, 1992; ISBN 978-026-258-130-1.

20. Wilber, K.A. Theory of Everything: An Integral Vision for Business, Politics, Science, and Spirituality; Shambhala: Boston, MA, USA, 2000; ISBN 978-161-180-452-2.

21. Mackey, J.; Sisodia, R.S. Conscious Capitalism, With a New Preface by the Authors: Liberating the Heroic Spirit of Business; Harvard Business School Publishing: Boston, MA, USA, 2014; ISBN 978-162-527-175-4.

22. Schumacher, E.F. Small Is Beautiful: A Study of Economics as if People Mattered; Blond \& Briggs: London, UK, 1973; ISBN 085-634-012-X.

23. Sisodia, R.S.; Sheth, J.; Wolfe, D. Firms of Endearment: How World-Class Companies Profit from Passion and Purpose, 2nd ed.; Pearson Education: Upper Saddle River, NJ, USA, 2014; ISBN 978-013-338-259-4.

24. Sisodia, R.; Gelb, M.J. The Healing Organization. Awakening the Conscience of Business to Help Save the World; HarperCollins Leadership: Nashville, TN, USA, 2019; ISBN 978-0-8144-3981-4.

25. Monegon, P.; Paul-Hus, A. The journal coverage of Web of Science and Scopus: A comparative analysis. Scientometrics 2016, 106, 213-228. [CrossRef]

26. Pritchard, A. Statistical bibliography or bibliometrics? J. Doc. 1969, 25, 348-349.

27. Rey-Martí, A.; Ribeiro-Soriano, D.; Palacios-Marqués, D. A bibliometric analysis of social entrepreneurship. J. Bus. Res. 2016, 69, 1651-1655. [CrossRef]

28. Web of Science. Available online: https://clarivate.com/webofsciencegroup/solutions/web-of-science/ (accessed on 7 May 2020).

29. Scopus Content Coverage Guide. Available online: https://www.elsevier.com/?a=694517.5.2020 (accessed on 7 May 2020).

30. Zhang, D.; Zhang, Z.; Managi, S. A bibliometric analysis on green finance. Current status, development, and future directions. Finance Res. Lett. 2019, 29, 425-430. [CrossRef]

31. Springer. Integral. Investing. Available online: https://www.springer.com/gp/book/9783030540159 (accessed on 13 August 2020).

32. Liu, C. Impact Investing: A Review of Literature and Ecosystem. In Intergenerational Governance and Leadership in the Corporate World; Puaschunder, J.M., Ed.; IGI Global: Hershey, PA, USA, 2019; pp. 191-217. ISBN 978-152-258-003-4.

33. Verrinder, N.B.; Zwane, K.; Nixon, D.; Vaca, S. Evaluvative tools in impact investing: Three case studies on the use of theories of change. Afr. Eval. J. 2018, 6, a340. [CrossRef]

34. Agrawal, A.; Hockerts, K. Impact investing: Review and research agenda. J. Small Bus. Entrep. 2019, 31, 1-29. [CrossRef]

35. United Nations. Sustainable Development Goals. Available online: https://www.un.org/sustainabledevelopment/ sustainable-development-goals/ (accessed on 20 August 2020).

36. United Nations. Global Issues Overview. Available online: https://www.un.org/en/sections/issues-depth/ global-issues-overview/ (accessed on 16 August 2020).

37. United Nations. Everyone Included: Social Impact of COVID-19. Available online: https://www.un.org/ development/desa/dspd/everyone-included-covid-19.html (accessed on 16 August 2020). 
38. Stahlhofer, N.J.; Schmidkonz, C.; Kraft, P. Conscious Business in Germany; Springer: Berlin/Heidelberg, Germany, 2017; ISBN 978-331-969-738-3.

39. Purpose. Steward-Ownership. Available online: https://purpose-economy.org/en/whats-steward-ownership/ (accessed on 13 August 2020).

40. Business Roundtable. Available online: https://opportunity.businessroundtable.org/wp-content/ uploads/2020/02/BRT-Statement-on-the-Purpose-of-a-Corporation-with-Signatures-Feb2020.pdf (accessed on 20 May 2020).

41. World Economic Forum. Davos Manifesto 2020: The Universal Purpose of a Company in the Fourth Industrial Revolution. Available online: https://www.weforum.org/the-davos-manifesto (accessed on 20 May 2020).

42. Schwab, K. Why We Need the 'Davos Manifesto' for a Better Kind of Capitalism. Available online: https://www. weforum.org/agenda/2019/12/why-we-need-the-davos-manifesto-for-better-kind-of-capitalism/ (accessed on 20 May 2020).

43. Fernandes Bella, R.L.; Gonçalves Quelhas, O.L.; Toledo Ferraz, F.; Soares Bezerra, M.J. Workplace spirituality: Sustainable work experience from a human factors perspective. Sustainability 2018, 10, 1887. [CrossRef]

44. Nicola, M.; Alsafi, Z.; Sohrabi, C.; Kerwan, A.; Al-Jabir, A.; Iosifidis, C.; Agha, M.; Agha, R. The socio-economic implications of the coronavirus and COVID-19 pandemic: A review. Int. J. Surg. 2020. [CrossRef] [PubMed]

45. Tashanova, D.; Sekerbay, A.; Chen, D.; Luo, Y.; Zhao, S.; Zhang, Q. Investment Opportunities and Strategies in an Era of Coronavirus Pandemic. Working Paper. Available online: https://papers.ssrn.com/sol3/papers. cfm?abstract_id=3567445 (accessed on 18 May 2020).

46. Chan Zuckerberg Initiative. Available online: https://chanzuckerberg.com/ (accessed on 21 May 2020).

47. Sady, M.; Żak, A.; Rzepka, K. The Role of Universities in Sustainability-Oriented Competencies Development: Insights from an Empirical Study on Polish Universities. Adm. Sci. 2019, 9, 62. [CrossRef]

(C) 2020 by the authors. Licensee MDPI, Basel, Switzerland. This article is an open access article distributed under the terms and conditions of the Creative Commons Attribution (CC BY) license (http://creativecommons.org/licenses/by/4.0/). 